\title{
肝内結石症治療の検討
}

\begin{tabular}{lrrrrr}
\multicolumn{8}{c}{ 金沢大学医学部第 2 外科 } & \\
木南 & 義男 & 宮崎 & 逸夫 & 永川 & 宅和 \\
倉知 & 圓 & 野口 & 昌邦 & 小西 & 孝司 \\
高田 & 道明 & 松葉 & 明 & &
\end{tabular}

\section{A STUDY ON TREATMENT OF INTRAHEPATIC LITHIASIS}

\section{Yoshio KINAMI, Itsuo MIYAZAKI, Takuwa NAGAKAWA, Madoka KURACHI, Masakuni NOGUCHI, Koji KONISHI, Michiaki TAKATA and Akira MATSUBA}

Department of Surgery II, School of Medicine, Kanazawa University, Kanazawa

過去18年間に著者らの施設に括いて治療した肝内結石症 94 例の胆管性状と手術々式および手術成績との 間の関連を検討した. 全症例に括いて, 退院時遺残結石率は $28 \%$ あ゙あ, 手術死亡率は7.4\%であった。 耐術例の遠隔成績では症例の $56 \%$ が良好を，29\%が軽快を，8\%が不変を，2\%が胆管炎による死亡を， 5\%が不明を示した．多くの症例においてては胆管の拡張や狭窄所見などに基ついた術式の選択が行われた が，肝内胆管の衰状抎張例や狭窄例では，これをみない例に比し，治療成績が劣った．また，肝内外胆管 狭窄を有する難治例に対しては肝切除, 肝内烥管切開截石拉よび肝管空腸吻合などを主とする術式が良好 な成績を表わし，それらの有效性が示唆された。

索引用語：肝内結石症, 胆管性状

\section{はじめに}

胆石症のらちでも肝内結石症は最も治療が困難である とされ，手術成績もいま一歩の感があることは否定でき ない、しかしながら，近年において胆道直接造影法，超 音波診断法あるいは CT 診断法などの 診断方法の進歩 につれ，手術方法にも工夫がなされ，また，各種の器具 ならびに結石溶解剤を駆使した結石除去法の改善も認め られている.

1976年に自験例の治療成績1)を検討したが，本症の難 治性が認められ, Wen ら 2)が述べている如く, とくに胆 管狭窄を有する症例の治療汇課題があることを示した。 その後, 胆管性状に基つくく手術々式の選択を試みている が，若干の治療成績の向上が得られている.

著者らは過去18年間に取扱った肝内結石症例の手術々 式と手術成績を検索するとともに，現在，実施している 治療の検討を行ったところ, 可成りの知見を得たので述 ベる.

\section{I 症例および方法}

過去18年間（1962１979年）に教室および一部の関連 施設に拈いて，肝内結石症94例が治療された。これらの 症例の 平均年龄 は52歳（22７2歳）であり，男女比は 1：1（47：47）であった。 また，病脳期間についてみ ると, 症例の $44 \%$ (41例) が 1 年以内で，34\% (32例) が $1 \sim 10$ 年であり， $22 \%$ (21例) は 10 年以上に拉よんで いた.

全例において各種の手術が行われているが、これらの 手術々式と胆管性状，退院時結石遺残率括よび遠隔成績 との関保を検討した. 胆管の形態学的検索は術中胆道造 影所見，PTCや ERCP 所見および胆道鏡所見などによ り行ったが，最近例では超音波診断や CT 所見む参考 とした，また，遠隔時治療成績は問診ならびにアンッー ト方式により実施した。これらの成績判明率は $96 \%$ \%゙あ り, 術後の経過年数は $1 \sim 18$ 年におよんでいた. 


\section{II 成}

1）手術および手術死亡率

手術々式としては，多彩なものをみるが，主として5 種類の術式に大別される（表 1 ）。著者らの施設におけ る最終手術々式として，胆摘を含む総胆管切開 $\mathrm{T}$ 字管挿 入は症例の $25 \%$ にこれに乳頭形成術が付加された術式 は36\%に，これら 2 術式のいずれかに䀒内胆管切開が加 えられたものは $6 \%$ ，胆管と十二指腸または空腸との 吻合術が主である術式は23\%に，肝切除術が主である術 式は10\%にそれぞれ実施されている．一方，術後処置と して全症例の68\%に胆管洗淮（結石溶解放使用を含さ） や胆道鏡使用による結石除去が行われた．肝切除術例で は67\%がこれらの術後処置を必要としなかったが，他の 術式に揖いては65〜 78\%の症例が何らかの術後処固を受

表 1 手術々式および症例数

\begin{tabular}{|c|c|}
\hline 手術術式* & 症例数 $(\mathscr{6})$ \\
\hline (1) 総胆管切開 $\mathrm{T}$ 字管挿入術 & $23(25)$ \\
\hline (2) (1)十乳頭形成術 & $34(36)$ \\
\hline (3) (1)または(2)十肝内胆管切開術 & $6(6)$ \\
\hline (4) 胆管陽管吻合清 & $22(23)$ \\
\hline 1）総胆管十二指腸吻合術 & 4 \\
\hline 2）総胆管空腸吻合術 & 11 \\
\hline 3) 肝管空渴㕫合街 & 6 \\
\hline 4）左肝内胆管空腸吻合術 & 1 \\
\hline (5) 訮切捈術 & $9(10)$ \\
\hline 合 & $94(100)$ \\
\hline
\end{tabular}

* : 胆震摘出術, 截石術を含む
けた，胆管腸管吻合術例では胆道鏡使用頻度が $46 \%$ と高 率であるのに対し，他の術式では胆道洗涤が50～56\%と 多くなっている.

寸でに他施設で行われた手術を含む手術回数について みると, 全例中, 1 回のみのものは55\%(51例)，2 回 のものは36\% (34例), 3 回のものは $4 \%$ ( 4 例), 4 回 のものは $3 \%$ (3 例) および 5 回のものは $2 \%$ ( 2 例) であった. 1 カ月以内の手術死亡は 7 例 $(7.4 \%)$ であ る. そのうち，5例は化膿性胆管炎に基因する敗血症や 急性腎不全により，他の 2 例は門脈内血栓症あるいは消 化管出血により死亡した.

2）手術々式と胆管性状

全症例に括ける胆管の形態学的所見 は以下の如くで あった（表 2 ）。肝外胆管のみに 扗張をみたものは 6 例 (6\%) に過ぎないが，肝内胆管の単純払張は47例 (50 \%) で，裹状拡張を認めたものは41例（44\%）であっ た. 胆管狭窄についてみると, 肝外胆管狭窄のみを示し たすのは18例 (19\%) で，肝内ならびに肝内外胆管狭窄 例は30例 (32\%) および14例（15\%）であり，狭窄を認 めなかったものは32例（34\%）であった.

ところで, 総胆管切開 $\mathrm{T}$ 字管插入術では単純肝内胆管 扗張あるいは非胆管狭窄の症例がいずれも過半数以上を 占めるが，乳頭形成術付加では非胆管狭窝例が少なくな る. 胆管腸管吻合術に㧊いては震状払張例の增加（68 \%) と非胆管狭窄例が更に減り，また，肝切除術は肝内 および肝内外胆管狭窄例のみに限られている.

3）手術々式別治療成績

手術々式別治療成績についてみると, 肝切除術例では 8 例 (89\%) に結石の完全除去が行われているのに対

表 2 手術々式と胆管性状との関係

\begin{tabular}{|c|c|c|c|c|c|c|c|c|c|}
\hline & \multirow{3}{*}{ 手術術式 } & \multirow{3}{*}{ 全症例数 } & \multicolumn{3}{|c|}{ 胆管 拡 張 } & \multirow{2}{*}{\multicolumn{2}{|c|}{ 胆＼cjkstart管 }} & \multirow{2}{*}{ 狭 } & \\
\hline & & & \multirow{2}{*}{ 肝外 } & \multicolumn{2}{|c|}{ 肝 内 } & & & & \\
\hline & & & & 単純 & 震状 & 肝外 & 肝内 & 肝内外 & なし \\
\hline (1) & 総胆管切開 $T$ 字管挿入術 & 23 & $3(13)$ & $15(65)$ & $5(22)$ & $3(13)$ & $6(26)$ & $1(4)$ & $13(57)$ \\
\hline (2) & (1)十乳頭形成術 & 34 & $2(6)$ & $20(59)$ & $12(35)$ & $10(29)$ & $7(21)$ & $5(15)$ & $12(35)$ \\
\hline (3) & (1), (2)十肝内胆管切開術 & 6 & 0 & $2(33)$ & $4(67)$ & 0 & $4(67)$ & 0 & $2(33)$ \\
\hline (4) & 胆管腸管吻合術 & 22 & $1(5)$ & $6(27)$ & $15(68)$ & $5(23)$ & $5(23)$ & $7(31)$ & $5(23)$ \\
\hline (5) & 肝切除術 & 9 & 0 & $4(44)$ & $5(56)$ & 0 & $8(89)$ & $1(11)$ & 0 \\
\hline & 計 & 94 & $6(6)$ & $47(50)$ & $41(44)$ & $18(19)$ & $30(32)$ & $14(15)$ & $32(34)$ \\
\hline
\end{tabular}


表 3 全症例の手術々式別治療成績

\begin{tabular}{|c|c|c|c|c|c|c|c|c|c|c|c|}
\hline \multirow{2}{*}{\multicolumn{2}{|c|}{ 手術術式 }} & \multicolumn{4}{|c|}{ 退院時結石 } & \multicolumn{6}{|c|}{ 耐術例遠隔成績* } \\
\hline & & 症例数 & 遗残 & なし & 不明 & 症例数 & 良好 & 軽快 & 不変 & 不明 & $\begin{array}{l}\text { 盟管 } \\
\text { 炎死 }\end{array}$ \\
\hline (1) & 総胆管切開 $\mathrm{T}$ 字管挿入術 & 23 & $7(30)$ & $15(65)$ & $1(5)$ & 20 & $12(60)$ & $5(25)$ & $2(10)$ & $1(5)$ & 0 \\
\hline (2) & (1)十乳頭形成術 & 34 & $10(29)$ & $23(68)$ & $1(3)$ & 32 & $18(56)$ & $9(28)$ & $3(10)$ & $2(6)$ & 0 \\
\hline & (1), (2)十肝内胆管切開術 & 6 & $2(33)$ & $3(50)$ & $1(17)$ & 5 & $3(60)$ & $1(20)$ & 0 & 0 & $1(20)$ \\
\hline (4) & 胆管腸管吻合術 & 22 & $6(27)$ & $13(59)$ & $3(14)$ & 22 & $10(45)$ & $9(40)$ & $1(5)$ & $1(5)$ & $1(5)$ \\
\hline (5) & 肝切除術 & 9 & $1(11)$ & $8(89)$ & 0 & 8 & $6(76)$ & $1(12)$ & $1(12)$ & 0 & 0 \\
\hline & 合 計 & 94 & $26(28)$ & $62(66)$ & $6(6)$ & 87 & $49(56)$ & $25(29)$ & $7(8)$ & $4(5)$ & $2(2)$ \\
\hline
\end{tabular}

し，他の術式例においては結石除去率は50〜68\%であり 術式間に著差をみない。一方，いずれの術式において も，耐術例の退院後経過で軽快以上をみた症例は80〜88 \%であったが，良好例に限ってみると肝切除術例の $76 \%$ が最も高率であり，他の術式例では45～60\%であった. また, 病状不変例は訮内胆管切開術例における $0 \%$ を除 き，いずれの術式例についても5１2\%程度に認められ た(表 3 ).

ところで，胆管腸管吻合術例中，肝管空腸吻合例には 結石遺残を認めていないが，総胆管十二指腸吻合術例や 総胆管空腸吻合術例では25および36\%の結石遺残となっ ている. また，肝管空腸吻合術例の 経過良好例は67\% で，他の術式例（０５0\%）に比し，治療成績が良好で あった（表 4 ）.

\section{4）耐術例の遠隔成績}

87例全ては手術後 1 18年経過しているが，56\%の症 例は退院後にまったく異常所見を認めていない，29\%の 症例は 1 年に数回軽度の胆管炎症状を示すが， $8 \%$ 症 例は最終手術前の病態と大差をみず，2\%（2例）は 4 年および 5 年後に化膿性胆管炎で死亡した. 一方, 良好 な経過を示した 4 例と不変となった 2 例が，術後 6 力月
から 7 年の間に，他病死した.すなわち，1 例は脳出血 により，5 例は悪性尰瘍（胆管癌 3 例，胃癌 1 例，蝢部 腫瘍 1 例）により死亡している.

5）胆管性状と治療成績

肝内胆管扗張所見および胆管狭窄所見と治療成績との 関連を検討した.

症例を肝内胆管払張無し，単純払張，䨢状抎張および 胆管狭窄を合併した拡張の 4 群に分け，各群の治療成績 を検索した（表 5 ）。なお，退院時結石遺残不明例およ び遠隔成績不明例は除外した. 肝内胆管拡張のない例で は遺残結石をみないが，単純払張例 (12\%), 㕠状拡張 例 $(20 \%)$, 胆管狭窄合併払張例 $(38 \%)$ の順飞遺残結 石率の增加をみた. 一方, 耐術例の遠隔成績についてみ ると，軽快以上を示すものでは各胆管性状別に著差をみ ないが，良好例に限ると慗状払張例や胆管狭窄合併払張 例では60\%および50\%と他の性状例（80，79\%）に比し 低率となった。 また，胆管狭窄合併扗張例では $11 \%$ の不 変例が認められた。

次に，症例を胆管狭窄なし，乳頭部を含む肝外胆管狭 窄, 肝内䏣管狭窄および肝内外胆管狭窄の 4 群に分け; 各群の治療成績を検索した（表6），遗残結石率は狭窄

表 4 胆管空腸吻合術例の術式別治療成績

\begin{tabular}{|c|c|c|c|c|c|c|c|c|c|c|}
\hline \multirow{2}{*}{ 手術 術 式 } & \multicolumn{4}{|c|}{ 退院時結石 } & \multicolumn{6}{|c|}{ 耐術例遠隔成績 } \\
\hline & 症例数 & 遭残 & なし & 不明 & 症例数 & 良好 & 軽快 & 不変 & 不明 & $\begin{array}{l}\text { 胆管 } \\
\text { 炎死 }\end{array}$ \\
\hline 1）総胆管十二指腸吻合術 & 4 & $1(25)$ & $2(50)$ & $1(25)$ & 4 & $2(50)$ & $1(25)$ & $1(25)$ & 0 & 0 \\
\hline 2) 総胆管空晹吻合術 & 11 & $4(36)$ & $5(46)$ & $2(18)$ & 11 & $4(36)$ & $6(55)$ & 0 & $1(9)$ & 0 \\
\hline 3) 肝管空腸吻合術 & 6 & 0 & $6(100)$ & 0 & 6 & $4(67)$ & $2(33)$ & 0 & 0 & 0 \\
\hline 4) 左肝内胆管空腸吻合術 & 1 & $1(100)$ & 0 & 0 & 1 & 0 & 0 & 0 & 0 & $1(100)$ \\
\hline
\end{tabular}


表 5 肝内胆管厸張所見と手術成績

\begin{tabular}{|c|c|c|c|c|c|c|c|c|c|}
\hline \multirow{2}{*}{\multicolumn{2}{|c|}{ 肝内胆管拡張所見 }} & \multicolumn{3}{|c|}{ 退院時結石 * } & \multicolumn{5}{|c|}{ 酎術例遠隔成績* } \\
\hline & & \multirow{2}{*}{$\begin{array}{c}\text { 症例数 } \\
6\end{array}$} & \multirow{2}{*}{$\begin{array}{c}\text { 遭残 } \\
0\end{array}$} & \multirow{2}{*}{$\begin{array}{l}\text { なし } \\
6(100)\end{array}$} & \multirow{2}{*}{$\frac{\text { 症例数 }}{5}$} & \multirow{2}{*}{$\begin{array}{l}\text { 良好 } \\
4(80)\end{array}$} & \multirow{2}{*}{$\begin{array}{l}\text { 軽快 } \\
1(20)\end{array}$} & \multirow{2}{*}{$\begin{array}{l}\text { 不変 } \\
0\end{array}$} & \multirow{2}{*}{ 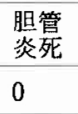 } \\
\hline な & L & & & & & & & & \\
\hline 単 & 純 & 17 & $2(12)$ & $15(88)$ & 19 & $15(79)$ & $3(16)$ & $1(5)$ & 0 \\
\hline 蕙 & 状 & 5 & $1(20)$ & $4(80)$ & 5 & $3(60)$ & $1(20)$ & 0 & $1(20)$ \\
\hline \multicolumn{2}{|c|}{ 胆管狭窄合併 } & 60 & $23(38)$ & $37(62)$ & 54 & $27(50)$ & $20(37)$ & $6(11)$ & $1(2)$ \\
\hline \multicolumn{2}{|c|}{ 計 } & 88 & $26(30)$ & $62(70)$ & 83 & $49(59)$ & $25(30)$ & $7(9)$ & $2(2)$ \\
\hline
\end{tabular}

表 6 胆管狭窄所見と手術成績

\begin{tabular}{|c|c|c|c|c|c|c|c|c|}
\hline \multirow{2}{*}{ 㫜管狭咋所見 } & \multicolumn{3}{|c|}{ 退院時結石 * } & \multicolumn{5}{|c|}{ 耐術例遠隔成績* } \\
\hline & 症例数 & 道残 & なし & 症例数 & 良好 & 軽块 & 不変 & $\begin{array}{l}\text { 䏣管 } \\
\text { 炎死 }\end{array}$ \\
\hline 肝 外 & 17 & $5(29)$ & $12(71)$ & 16 & $9(56)$ & $4(25)$ & $2(13)$ & $1(6)$ \\
\hline 肝 内 & 29 & $11(38)$ & $18(62)$ & 24 & $11(46)$ & $10(42)$ & $3(12)$ & 0 \\
\hline 肝内外 & 14 & $7(50)$ & $7(50)$ & 14 & $7(50)$ & $6(43)$ & $1(7)$ & 0 \\
\hline な ᄂ & 28 & $3(11)$ & $25(89)$ & 29 & $22(75)$ & $5(17)$ & $1(4)$ & $1(4)$ \\
\hline 計 & 88 & $26(30)$ & $62(70)$ & 83 & $49(59)$ & $25(30)$ & $7(9)$ & $2(2)$ \\
\hline
\end{tabular}

のない例 $(11 \%)$, 肝外胆管㹨窄例 $(29 \%)$, 肝内胆管狭 窄例 $(38 \%)$, 肝内外胆管狭窄例 $(50 \%)$ の順に増加し た. 一方，耐術例の遠隔成績についてみると，良好を 示したものは胆管狭窄 のない例が75\%で，他の狭窄例 （46〜56\%）に比し，高率であった：また，胆管狭窄の ない例は不変が $4 \%$ で各狭窄例（7１3\%）より低率を 示した。

6）胆管狭窄例の術式別治療成績

肝外，肝内および肝内外胆管に狭窄を認めた症例につ き，手術々式別に治療成績を検索し，以下の所見を得た
（表 7）。なお, 退院時結石遺残不明例および 遠隔成績 不明例は除外した。

結石遗残率では，肝切除術例が11\%（1 例）で他の術 式例（40５0\%）に比し最も低率であった. 耐術例の遠 隔成績についてみると, 軽快以上の成績を示したものは 肝内胆管切開術例 ( 3 例, 100\%) 以外の術式例（78～ 89\%）間において著差を認めなかった. しかし，良好 例に限ってみると肝切除術例が76\%で他の術式例（38〜 67\%）との間に差をみた. 一方，不変を示したものにつ いてみると，胆管腸管吻合術例が $6 \%$ と最も低率であ

表 7 胆管狭窄例の術式別治療成績

\begin{tabular}{|c|c|c|c|c|c|c|c|c|}
\hline \multirow{2}{*}{ 手術術 式 } & \multicolumn{3}{|c|}{ 退院時結石 * } & \multicolumn{5}{|c|}{ 耐術例遠隔成績* } \\
\hline & 症例数 & 遭残 & なし & 症例数 & 良好 & 軽快 & 不変 & $\begin{array}{l}\text { 盟管 } \\
\text { 炎死 }\end{array}$ \\
\hline (1) 総胆管切開 $\mathrm{T}$ 字管捙入術 & 10 & $4(40)$ & $6(60)$ & 9 & $4(45)$ & $3(33)$ & $2(22)$ & 0 \\
\hline (2) (1)十乳頭形成術 & 22 & $10(45)$ & $12(55)$ & 18 & $9(50)$ & $7(39)$ & $2(11)$ & 0 \\
\hline (3) (1), (2)十肝内胆管切開術 & 4 & $2(50)$ & $2(50)$ & 3 & $2(67)$ & $1(33)$ & 0 & 0 \\
\hline (4) 胆管腸管吻合術 & 15 & $6(40)$ & $9(60)$ & 16 & $6(38)$ & $8(50)$ & $1(6)$ & $1(6)$ \\
\hline (5) 肝切除術 & 9 & $1(11)$ & $8(89)$ & 8 & $6(76)$ & $1(12)$ & $1(12)$ & 0 \\
\hline
\end{tabular}


表 8 胆管狭窄例に対する胆管腸管吻合術の術式別治療成績

\begin{tabular}{|c|c|c|c|c|c|c|c|c|}
\hline \multirow{2}{*}{ 手 術 術 式 } & \multicolumn{3}{|c|}{ 退院時結石 ${ }^{*}$} & \multicolumn{5}{|c|}{ 耐術例遠隔成績* } \\
\hline & 症例数 & 遭残 & なし & 症例数 & 良好 & 軽快 & 不変 & $\begin{array}{l}\text { 盟管 } \\
\text { 炎死 }\end{array}$ \\
\hline 1）総胆管十二指腸吻合術 & 2 & $1(50)$ & $1(50)$ & 3 & $1(33)$ & $1(33)$ & $1(33)$ & 0 \\
\hline 2）総胆管空腸吻合術 & 7 & $4(57)$ & $3(43)$ & 7 & $2(29)$ & $5(71)$ & 0 & 0 \\
\hline 3）肝管空腸吻合術 & 5 & 0 & $5(100)$ & 5 & $3(60)$ & $2(40)$ & 0 & 0 \\
\hline 4）左肝内胆管空腸吻合術 & 1 & $1(100)$ & 0 & 1 & 0 & 0 & 0 & $1(100)$ \\
\hline
\end{tabular}

り，総胆管切開 $\mathrm{T}$ 字管插入術例が $22 \%$ と最も高率であっ た．ところで，胆管腸管吻合術例のうち，肝管空腸吻合 術例では完全結石除去がなされ，遠隔成績においても60 \%が良好を示し，不変例を認めなかったまた，総胆管 空腸吻合術例は遺残結石率が57\% と高く，他方，遠隔成 樍において軽快以上例は $100 \%$ となるが，良好をみたも のは $29 \%$ に過ぎなかった（表 8 ).

\section{III 考 察}

著者らの肝内結石症例の男女比は $1 ： 1$ であり，1976 年の木下らの全国集計例”之明らかな差をみないが, Wen ら ${ }^{2)}$ の症例に和恬る男女比 $3.4: 1$ との間に相違をみ る. また，本症の年龄分布では30 60歳台に患者の発

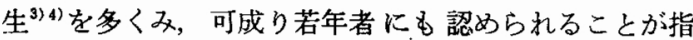
摘されているが，自験例においてもこの傾向をみる。一 方，教室での治療以前の病脳期間についてみると，22\% もの症例が 10 年以上におよぶ期間を有し，本症における 治療上の問題点を示唆している.

ところで, 肝内結石症の手術々式には多彩なものがみ られる. 自験例に扣いても胆摘を含む総胆管切開 $\mathrm{T}$ 字管 挿入術をはじめとして，5種類に大別される術式を認め る、しかしながら，いずれの症例においても複数の術式 の組合せからなる手術が行われているが，Wen ら² は

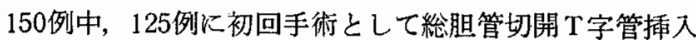
術を行っている．また，久次 ${ }^{5)}$ の報告において 26 あ術 式をみるる症例 の $40 \%$ は総胆管切開ドレナージ術を受 け，1976年の著者らの報告例 ${ }^{1}$ でも $46 \%$ が総胆管切開 字管挿入術を実施されている. Sato $ら^{6)}$ は，主な手術々 式として肝門部までにおよぶ桩大胆管切開術（55\%）を あげ，胆管ドレナージなどの付加手術を併用している. これらの報告は総胆管切開による截石ドレナージ術が基 本術式であることを表し，本法と他の術式との組合せが 行われていることを示す．とくに以前の症例注どそれら の術式を受けていた傾向が大であると推察される。しか
し，今回検索した自験例では肝切除術例は $10 \%$ で, 各種 の胆管腸管吻合術例は $23 \%$ ありり，前回の症例のこれら の此率がいずれも $3 \%$ 程度であったのに比し, 手術内容 汇可成りの変化が認められる.

如何なる手術々式を選択するかは，胆管性状，あるい は術後にお斿る遺残結石に対する処置などにより異なる ことは当然といえょう，自験例についてみると，総胆管 切開術は肝内胆管単純抁張例や胆管狭窄のない例に最む 施行頻度が高く, 乳頭形成術の付加も同様の症例に対し 可成り行われている. 肝内胆管切開術は肝内胆管の衰状 抎張例や狭窄例飞, 胆管腸管吻合術子肝内胆管震状払張 例に多く行われている。 また，肝切除術は一側肝葉内に 結石が比較的限局し, 肝内胆管狭窄をみる例に高率に実 施されている。しかしながら，必ずしも術式の選択が適 切であったとはいい難い例もある。

胆管性状で手術成績と最も関係の深いものは肝内胆管 狭窄を有する症例であり, 最近, 術式について各報告者 の工夫がみられる. Sato ら ${ }^{6)} 17 \%$ に肝内胆管切開術と 27\%に肝切除術を行って拈り, Pridgen ら”は結石をみ た Caroli's disease に対し肝切除術あるい、総胆管空腸 吻合術を試み，Fang $5^{8)}$ 蜹禹僋肝内結石症に対し皮下 飞 blind loop を有する肝管空腸側々吻合術を行ってい る.また, Simi ら゙は端側あるいは側々肝腸吻合術を高 頻度に施行し, Burhenne ${ }^{9)}$ は肝内胆管狭窄を有する症例 の遺残結石に対する処置として非手術的に U tube の応 用を示している.これらの手術々式や処置は術後の遺残 結石についての対策となっているが，わが国に扮いても この点を考慮した手術々式 ${ }^{10111}$ が可成り以前より実施さ れてきた，日等ら ${ }^{12)}$ は術後に括计る遺残結石の截石を目 的とした総肝管空腸吻合術兼外瘻術を示しているが，著 者らの施設においても17例（18\%）が同椂の目的で総胆 管あるいは総肝管空腸吻合術（端側）を受けている。

術中に淤ける結石の完全除去は理想ではあるが，胆管 
性状や結石状態あるいは症例の病態などにより結石遺

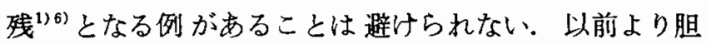
管外瘦を利用した胆管洗條が行われてきたが，著者らの 症例においても $47 \%$ に本法が実施されている. 久次 ${ }^{5)}$ の 報告にみられる如く, 結石溶解㓮としてへキサィタ燐酸 ソーダーあるいは GA-100などが自験例に拈いても使用 されたが，前者の効果は必ずしも良好ではなかった。一 方, 胆道鏡を用いた各種器具による遺残結石除去は, 最 近例において多く行われており, 胆管洗涤との組合せに より可成りの成績を得ている. 従って, 症例により異な るが, 初回手術において, これらの術後処置1)68)をも考 虑した手術々式を選択すべきであることが示唆される. 実際に自験例でる $45 \%$ か 2 回以上の手術を受けている が，この点の配慮により手術回数の減少を可成りの例に 期待出来ると考えている.

全症例の退院時における結石遺残は28\%であったが， 手術々式別では肝切除例が11\%で最低率を示し, 他の術 式例では27〜33\%の結石遺残をみた. この成績は以前に 報告 ${ }^{1)}$ した遺残結石率との間に著差を認めない。しかし， 少数例ではあるが, 最近実施している肝管空腸吻合術例 では退院時に結石の遺残をみない.すなわちここの術式 は術後の遺残結石除去に有効なことを表している. 本症 の治療成績は結石所見（数や存在部位）や胆管性状に左 右されることは明らかであり, 著者らはこの点を先に指 摘”した。 Simi ら は, 胆管拡張が術後の経過に著明に 影響することを考察し, $2 \mathrm{~cm}$ 以上の胆管拡張例に肝腸吻 合術を行っている. また, Pridgen らうゃ Mathias ら の結石を伴う Caroli's disease の報告にみられる如き, 肝内胆管の謈状払張例は可成りの率（自験例 $44 \%$ ）に認 められる.なんらかの胆管狭窄を伴らため，この衣状払 張は結石除去の直接成績および遠隔成績に著しく影響を およばし, 著者らの售状拡張例の手術成績む単純払張例 との比較においてこの点を明らかに示している.

胆管性状で最も手術成績と関連の深いものは胆管狭窄 の有無であることは, 今回の検索に打いても認められ, 肝内狭窄をみる症例の遺残結石率および遠隔成績は胆管 㹟窄のない例や肝外狭窄例に比し不良であった．GIenn

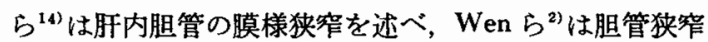
例が難治性である点を指摘しているが,これらはいず れも肝内胆管狭窄を有する症例の治療に最も課題がある ことを示している．自験例で胆管狭窄をみた症例につき 手術々式別に治療効果を検討したが, 肝切除例が遺残結 石率や遠隔時良好率において最す良い成績を示する，他
の術式間ではこれらの成績に著差をみなかった. しか し，最近において実施している肝管空腸吻合術では可成 り治療成績の向上が得られた，本法は同様の吻合を行う 総胆管空腸吻合術に比し明らかに治療効果が良好である が，その原因は高位肝管に吻合を行ったことに基づくと 推察される、すなわち, 術中, 術後とも胆道鏡を利用し た結石除去において，この術式は有利なことを示唆して いる、ところで，最む重要である胆管狭窄あるいは肝内 胆管衰状払張をみる症例においては（1) 胆管狭窄の除 去，(2) 結石の可能な限りの排除，(3) 術後あるいは遠 隔時における遺残または再発結石に対する処置法などを 充分考虑した手術々式が望まれる．これらの点を含む術 式として, 現在推察されるものは blind loop を有する 肝管空腸吻合術, 肝内胆管切開術および肝切除術などで あり，それらの組合せによる手術方法であろう。

自験例中，遠隔時に不変を示したものは 7 例 $(8 \%)$ であったが，以前に実施された総胆管切開 $\mathrm{T}$ 字管插入術 2 例とこれに乳頭形成術を付加した 3 例を含んでいる. これらの症例は手術々式の選択に問題があったと推測さ れる. しかしながらこのうちには全治したと思われた にも拘らず18年後に結石再発をみ不変となった例すある ことからして, 本症の難治性が示唆され, 治療後に拈け る長期間の患者管理が本症においては必須であると思わ れた。

\section{むすび}

肝内結石症94例の手術々式および手術成績を検索し， 以下の結果を得た.

1）手術々式は総胆管切開截石 $\mathrm{T}$ 字管挿入術, これに 乳頭形成術の付加, 肝内胆管切開截石術, 各種胆管腸管 吻合術および肝切除術の 5 術式に分けられた.

2）症例の $45 \%$ は 4回の再手術を受けていた. た，手術死亡は 7 例 $(7.4 \%)$ であり，5例は化膿性胆 管炎により失った.

3）全症例における退院時遺残結石率は28\%であり， 酎術例の遠隔成績では $56 \%$ が良好を，29\%が軽快を，8 \%が不変を，2\%が胆管炎による死亡を，5\%が不明を 示した。

4）胆管性状と治療成績との関連をみると，肝内胆管 䕊状拡張例および肝内胆管狭窄例は最も成績が不良で あった。

5）肝内外胆管狭窄例の術式別治療成績において肝切 除術例，肝内胆管切開截石術例および肝管空腸吻合術例 が良好な遠隔成績を表し，難治例に対するこれら術式の 
有効性が示唆された。

\section{文㰴}

1）木南義男ほか：手術成粸からみた肝内胆石症の 検討。臨床外科, 31 : 919-924, 1976.

2) Wen, C.C., et al.: Intrahepatic stones: a clinical study. Ann. Surg., 175: 166-177, 1972.

3) 木下博明：肝内胆石をめぐる諸問題一最近 5 年 間の疫学的統計。日臨外会誌，37：129-132， 1976.

4) Simi, M., et al.: Intrahepatic lithiasis, study of thirty-six cases and review of the literature. Am. J. Surg., 137: 317-322, 1979.

5）久次武晴：肝内胆石をめぐる諸問題一手術方式 と予後，打よび結石溶解珮纪ついて，日臨外会 誌, 37 ： 135-139，1976.

6) Sato, T., et al.: Results of surgical treatment for intrahepatic gallstones. Tohoku J. Exp. Med., 122: 303-312, 1977.

7) Pridgen, J.E., et al.: Primary intrahepatic gallstones. Arch. Surg., 112: 1037-1043, 1977.

8) Fang, K., et al.: Subcutaneous blind loop- a new type of hepaticocholedochojejunostomy for bilateral intrahepatic calculi. Chinese Medical J., 3: 413-418, 1977.

9) Burhenne, H.J., et al.: Retained intrahepatic stones. Use of the $U$ tube during repeated nonoperative stone extractions. Arch. Surg., 113: 837-841, 1978.

10) Nagamitsu, S., et al.: Wraparound end-toend hepaticojejunostomy (Roux-en-Y) for intrahepatic pigment calculi. Japanese J. Surg., 9: $49-54,1979$.

11) Nagase, M., et al.: Treatment of intrahepatic gallstones. Arch. Jap. Chir., 47: 467-473, 1978.

12）日笠頼則ほか：肝内結石截石のための総肝管空 渴吻合術兼外塿術. 臨床外科. $35: 57-64$, 1980.

13) Mathias, K., et al.: Intrahepatic cystic bile duct dilatations and stone formation: a new case of caroli's disease. Acta Hepato-Gastroenterol., 25: 30-34, 1978.

14) Glenn, F., et al.: Intrahepatic calculi. Ann. Surg., 153: 711-724, 1961. 